\title{
SAGEBRUSH, GREATER SAGE-GROUSE, AND THE OCCURRENCE AND IMPORTANCE OF FORBS
}

\author{
Victoria E. Pennington 1,5 , Daniel R. Schlaepfer 2 , Jeffrey L. Beck 3 , John B. Bradford ${ }^{4}$, \\ Kyle A. Palmquist ${ }^{1}$, and William K. Lauenroth ${ }^{1}$
}

\begin{abstract}
Big sagebrush (Artemisia tridentata Nutt.) ecosystems provide habitat for sagebrush-obligate wildlife species such as the Greater Sage-Grouse (Centrocercus urophasianus). The understory of big sagebrush plant communities is composed of grasses and forbs that are important sources of cover and food for wildlife. The grass component is well described in the literature, but the composition, abundance, and habitat role of forbs in these communities is largely unknown. Our objective was to synthesize information about forbs and their importance to Greater Sage-Grouse diets and habitats, how rangeland management practices affect forbs, and how forbs respond to changes in temperature and precipitation. We also sought to identify research gaps and needs concerning forbs in big sagebrush plant communities. We searched for relevant literature including journal articles and state and federal agency reports. Our results indicated that in the spring and summer, Greater Sage-Grouse diets consist of forbs (particularly species in the Asteraceae family), arthropods, and lesser amounts of sagebrush. The diets transition to sagebrush in fall and winter. Forbs provide cover for Greater Sage-Grouse individuals at their lekking, nesting, and brood-rearing sites, and the species has a positive relationship with arthropod presence. The effect of grazing on native forbs may be compounded by invasion of nonnative species and differs depending on grazing intensity. The effect of fire on forbs varies greatly and may depend on time elapsed since burning. In addition, chemical and mechanical treatments affect annual and perennial forbs differently. Temperature and precipitation influence forb phenology, biomass, and abundance differently among species. Our review identified several uncertainties and research needs about forbs in big sagebrush ecosystems. First, in many cases the literature about forbs is reported only at the genus or functional type level. Second, information about forb composition and abundance near lekking sites is limited, despite the fact that lekking sites are an important center of Greater Sage-Grouse activity. Third, there is little published literature on the relationship between forbs and precipitation and between forbs and temperature, thereby limiting our ability to understand potential responses of forbs to climate change. While there is wide agreement among Greater Sage-Grouse biologists that forbs are an important habitat component, our knowledge about the distribution and environmental responses of forb species in big sagebrush plant communities is limited. Our work for the first time synthesizes the current knowledge regarding forbs in sagebrush ecosystems and their importance for Greater Sage-Grouse and identifies additional research needs for effective conservation and management.
\end{abstract}

Resumen.-Los ecosistemas de artemisa (Artemisia tridentata Nutt) son el hábitat de especies silvestres como el urogallo de las artemisas (Centrocercus urophasianus). El sotobosque de las comunidades de plantas de artemisa grandes se compone de pastos y malezas que son importantes fuentes de cobertura y alimento para la fauna. El componente de pastos está bien descrito en la literatura, pero hay un vacío en el conocimiento de la composición, abundancia y el papel que juega el hábitat de especies herbáceas en estas comunidades. Nuestro objetivo fue sintetizar información sobre las plantas herbáceas y su importancia para las dietas y los hábitats de los urogallos, cómo las prácticas de manejo de los pastizales afectan a las plantas herbáceas y cómo éstas responden a los cambios de temperatura y precipitación. También intentamos identificar las deficiencias en las investigaciones y las necesidades de las plantas herbáceas en comunidades de plantas de artemisa grandes. Realizamos búsquedas generales en la literatura relevante, incluyendo artículos en revistas e informes gubernamentales y reportes de agencias federales. Nuestros resultados indican que, durante la primavera y el verano, la dieta de los urogallos consiste de hierbas, en particular de especies de la familia Asteraceae, artrópodos y, en menor medida, artemisas. Su dieta cambió a artemisas durante el otoño y el invierno. Las plantas herbáceas ofrecen cobertura a los urogallos en sus áreas de lek, anidación y lugares de cría, y tienen una relación positiva con la presencia de artrópodos. Los efectos del pastoreo en las plantas herbáceas nativas pueden agravarse con la invasión de especies no nativas, y difieren dependiendo de la intensidad del pastoreo. Los efectos del fuego en las plantas herbáceas son muy variables, y pueden depender del tiempo transcurrido desde la quema. Además, los tratamientos químicos y mecánicos afectan a las plantas herbáceas anuales y perennes de manera diferente. La temperatura y la precipitación influencian la fenología, la biomasa y la abundancia de las herbáceas de manera diferente entre especies. Nuestra revisión identificó varias incertidumbres y la necesidad de estudiar las plantas herbáceas en los ecosistemas de artemisa. En primer lugar, en muchos casos, la literatura informa sólo a nivel de género o funcional sobre las herbáceas. En segundo lugar, la información

\footnotetext{
IDepartment of Botany, University of Wyoming, Laramie, WY.

${ }^{2}$ Section of Conservation Biology, University of Basel, St. Johanns-Vorstadt 10, CH-4056, Switzerland.

${ }^{3}$ Department of Ecosystem Science and Management, University of Wyoming, Laramie, WY.

${ }^{4}$ U.S. Geological Survey, Southwest Biological Science Center, Flagstaff, AZ.

5E-mail: victoria.pennington4@gmail.com
} 
sobre la composición y la abundancia de las herbáceas cerca de áreas de lek es limitada, a pesar de que los sitios de lek son una parte importante de la actividad del urogallo. En tercer lugar, tenemos poca literatura sobre la relación entre las plantas herbáceas y las precipitaciones, así como de las herbáceas y la temperatura, lo cual limita nuestra capacidad para entender las posibles respuestas de las herbáceas al cambio climático. Nuestra conclusión general es que, si bien existe un amplio consenso entre los biólogos sobre que las herbáceas son un componente importante en el hábitat del urogallo, nuestro conocimiento sobre la distribución y las respuestas ambientales de las especies de plantas herbáceas en las comunidades de grandes plantas de artemisa es limitado. Nuestro trabajo sintetiza, por primera vez, el conocimiento actual con respecto a las plantas herbáceas en los ecosistemas de artemisa y su importancia para el urogallo, al mismo tiempo que identifica la necesidad de continuar investigando para encontrar un manejo y conservación eficaces.

Sagebrush (Artemisia L.) ecosystems occur in portions of western North America where soil water availability is limiting (Shumar and Anderson 1986, Schlaepfer et al. 2012) due to soil properties (Thatcher 1959), topography (Thatcher 1959), and climate (Daubenmire 1966). Sagebrush plant communities consist of a shrub overstory and an understory composed of forbs and grasses (Apostol and Sinclair 2006). The most widespread species of sagebrush is big sagebrush (Artemisia tridentata Nutt.) (Schultz 2012), and hence the focus of our paper. Big sagebrush grows mostly in upland areas (Thatcher 1959) at mean soil depths of 97-112 cm (Schlaepfer et al. 2012) and provides habitat for Greater Sage-Grouse (Centrocercus urophasianus) (Patterson 1952), Gunnison Sage-Grouse (Centrocercus mini$m u s$ ), and other sagebrush-obligate wildlife (Knick et al. 2003). There are 3 major big sagebrush subspecies found in North America: mountain big sagebrush (A. $t$. Nutt. ssp. vaseyana [Rydb.] Beetle), Wyoming big sagebrush (A. $t$. Nutt. ssp. wyomingensis Beetle \& Young), and basin big sagebrush (A. $t$. Nutt. ssp. tridentata). Mountain big sagebrush grows in udic soils and primarly at elevations between 2000 and $2800 \mathrm{~m}$, while Wyoming big sagebrush and basin big sagebrush grow in aridicxeric soils, with basin big sagebrush occurring between 1300 and $2200 \mathrm{~m}$ and Wyoming big sagebrush occurring between 800 and $2200 \mathrm{~m}$ (West 1988, NatureServe 2015).

Greater Sage-Grouse is a sagebrush-obligate bird that, prior to European settlement in North America, utilized an estimated 1.2 million $\mathrm{km}^{2}$ of habitat, of which approximately $668,000 \mathrm{~km}^{2}$ remains (Schroeder et al. 2004). The decrease in habitat is due to large wildfires (Nelle et al. 2000, Coates et al. 2015), overgrazing (Pedersen et al. 2003), human population expansion (Connelly et al. 2004), invasive species (Davies 2011), infrastructure (Braun 1998, Manier et al. 2013), and energy development (Smith et al. 2014, Holloran et al. 2015, Kirol et al. 2015). In response to reduced habitat, Greater Sage-Grouse populations have declined and are considered at risk throughout their geographic range in Alberta and Saskatchewan and in 11 states in the United States where they occur (Connelly and Braun 1997, Aldridge and Brigham 2003, Schroeder et al. 2004). In March 2010, Greater Sage-Grouse were given a designation of "warranted but precluded" for listing under the Endangered Species Act (USFWS 2010); but in September 2015, listing was not considered warranted (USFWS 2015). However, Greater Sage-Grouse continues to be a species of conservation and management concern throughout western North America.

Scientists have described seasonal habitat requirements for Greater Sage-Grouse for various life stages (Patterson 1952, Beck 1977, Schroeder et al. 1999, Connelly et al. 2000, Hagen et al. 2007). Herbaceous composition and structure are particularly important aspects of Greater Sage-Grouse habitat (Connelly et al. 2000) and can have concomitant influences on demographic rates, including nest survival (e.g., Doherty et al. 2014). Habitat guidelines for the breeding season suggest an understory height $>18 \mathrm{~cm}$ and understory canopy cover of $\geq 15 \%$ at arid sites and $\geq 25 \%$ at mesic sites (Connelly et al. 2000). During brood-rearing, an understory canopy cover $>15 \%$ is required by Greater Sage-Grouse, whereas in the winter, understory height is not applicable (Connelly et al. 2000), as sagebrush provides nearly exclusive food and cover to Greater Sage-Grouse (Eng and Schladweiler 1972, Beck 1977, Remington and Braun 1985, Smith et al. 2014).

Given that Greater Sage-Grouse are sagebrush obligates, understanding their habitat requirements in terms of sagebrush plant community composition and structure is important for conservation in the future (Connelly et al. 
2000, Hagen et al. 2007, Hess and Beck 2012). Although shrub and grass requirements are well described, our understanding of the requirements for forb composition and diversity in big sagebrush communities is limited.

Forbs are herbaceous vascular plants that are not members of the Cyperaceae, Juncaceae, or Poaceae families. They are important to Greater Sage-Grouse for 3 reasons: first, forbs are an important food source for both juvenile and adult Greater Sage-Grouse (Klebenow and Gray 1968, Peterson 1970, Wallestad and Eng 1975, Barnett and Crawford 1994, Drut et al. 1994b); second, although nesting and brood rearing are likely influenced primarily by grass and sagebrush cover and structure (Fischer et al. 1996a, Kirol et al. 2012), forbs provide essential cover to conceal Greater Sage-Grouse eggs, chicks, and adults from predators (Watters et al. 2002); and third, Greater Sage-Grouse consume arthropods (Klebenow and Gray 1968, Martin 1970, Peterson 1970, Wallestad and Eng 1975, Johnson and Boyce 1990, Drut et al. 1994b), and forbs are used by arthropods as host plants (Evans 1984, Porter and Redak 1997). In the spring and summer, Greater SageGrouse in many areas select for forb and grass cover that is suitable for nesting and brood rearing (Klebenow 1969, Peterson 1970, Wallestad 1971, Kirol et al. 2012). As soils dry in the summer months and forbs desiccate, Greater Sage-Grouse may relocate to nearby mesic areas with abundant green forbs (Klebenow 1969, Peterson 1970, Wallestad 1971, Fischer et al. 1996b).

Big sagebrush communities have been impacted by range management practices intended to release herbaceous understory. Before the mid-1970s, approximately $20,000 \mathrm{~km}^{2}$ of sagebrush on federal land had been burnedor chemically or mechanically treated-and seeded to exotic grasses, to provide forage for livestock (Vale 1974). Heavy grazing may influence the presence of forbs by allowing nonnative grasses to invade (Branson 1985, Davies 2011). Additionally, climate change is an emerging threat to big sagebrush communities. Global Climate Models (GCMs) suggest that temperatures in western North America will likely be warmer (IPCC 2013) and soils will likely be drier for longer time periods during the summer (Bradford et al. 2014, Klos et al. 2014, Palmquist et al. 2016). Climate change will likely affect the timing of snowmelt (Bradford et al. 2014), which may affect forb reproduction, phenology, and mortality (Inouye 2008). Given these climate projections and that anthropogenic disturbances will likely increase in the future, it is important to understand how forbs might respond to changes in temperature and precipitation.

Our objective was to compile information about the importance of forb species to Greater Sage-Grouse in sagebrush communities in western North America. Specifically, we examined (1) which forbs are commonly used by Greater Sage-Grouse during the processes of diet and habitat selection, (2) how rangeland management practices affect forb composition and biomass, and (3) how forbs respond to changes in temperature and precipitation and what implications those forb responses will have for Greater Sage-Grouse populations. This work, for the first time, brings together the currently available knowledge on the relationship between forbs in big sagebrush ecosystems and the Greater SageGrouse and helps identify knowledge gaps and important research needs.

\section{Methods}

We conducted a literature search through Web of Science (Thomson Reuters) and Google Scholar. On 1 November 2013, we obtained 158 results by searching for the words sagegrouse and forb in the title, abstract, or subject fields. Of those 158 articles, 90 were omitted because they contained only vague information about forbs or focused on mining or restoration methods such as seeding. Most journal articles were peer reviewed, but we also included non-peer-reviewed journal articles, agency reports, conference proceedings, books, master's theses, and doctoral dissertations. We classified papers into 4 sections according to study focus: Greater Sage-Grouse diet, Greater Sage-Grouse habitat, the relationship between forbs and rangeland management practices, and the relationship between forbs and temperature/precipitation. Because Greater Sage-Grouse diet and habitat requirements are seasonal, we considered this information separately for spring, summer, and fall/winter. Diet studies were selected and separated by those that were based on crop dissections and those that used direct 


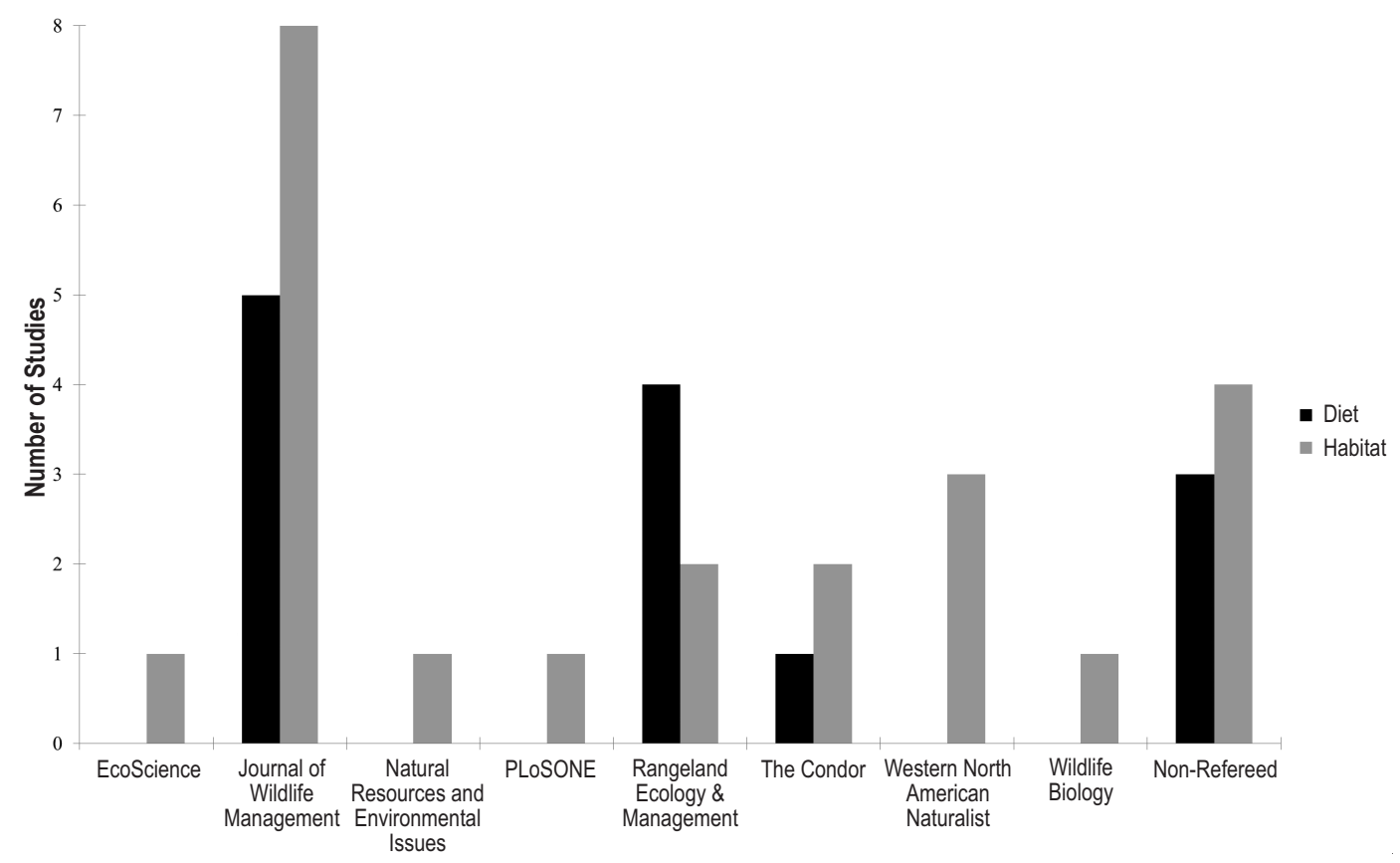

Fig. 1. Number of studies from journal and nonrefereed articles on Greater Sage-Grouse diet and habitat that contain information about forbs in big sagebrush plant communities in western North America. Of 158 articles initially obtained, 36 diet and habitat studies were detected from the Web of Science and Google Scholar. (Note: Western North American Naturalist includes articles from Great Basin Naturalist.)

observations of foraging Greater Sage-Grouse. Habitat studies were included if they had a direct association with Greater Sage-Grouse and if they evaluated microhabitat characteristics at Greater Sage-Grouse-used sites (e.g., nests and brood-rearing locations) compared to randomly available locations in sagebrush ecosystems. We report the big sagebrush subspecies involved in each study, unless the subspecies was not identified.

Both observational and experimental studies were grouped together in most sections, which may have resulted in different conclusions being drawn from these papers due to differences in methodology. Experimental studies were differentiated from observational studies if they had a control and a treatment group. To address studies with different conclusions, we identified conflicting studies that were in the same section and that had different conclusions, and we examined whether differences in methodology may have caused them. Although we were ultimately unable to determine whether differences in methods or real ecological differences were driving disparate conclusions, we do identify those conflicting studies and acknowledge that our synthesis of them should be interpreted with caution.

\section{Results and Discussion}

We categorized 68 sources based on whether the study addressed Greater SageGrouse use of forbs as a diet component (13 sources), investigated forbs as a habitat component (23), examined the relationship between forbs and rangeland management practices (24), or assessed the relationship between forbs and temperature/precipitation (8). There were a total of 22 studies that had conflicting results possibly due to different methods, different years, different locations, or different study areas.

\section{Diet}

Thirteen diet studies were included from Rangeland Ecology and Management, Journal of Wildlife Management, The Condor, and various non-peer-reviewed sources (Fig. 1). Seven $(54 \%)$ of these studies were published in the 1990s or later (Fig. 2). There were 12 


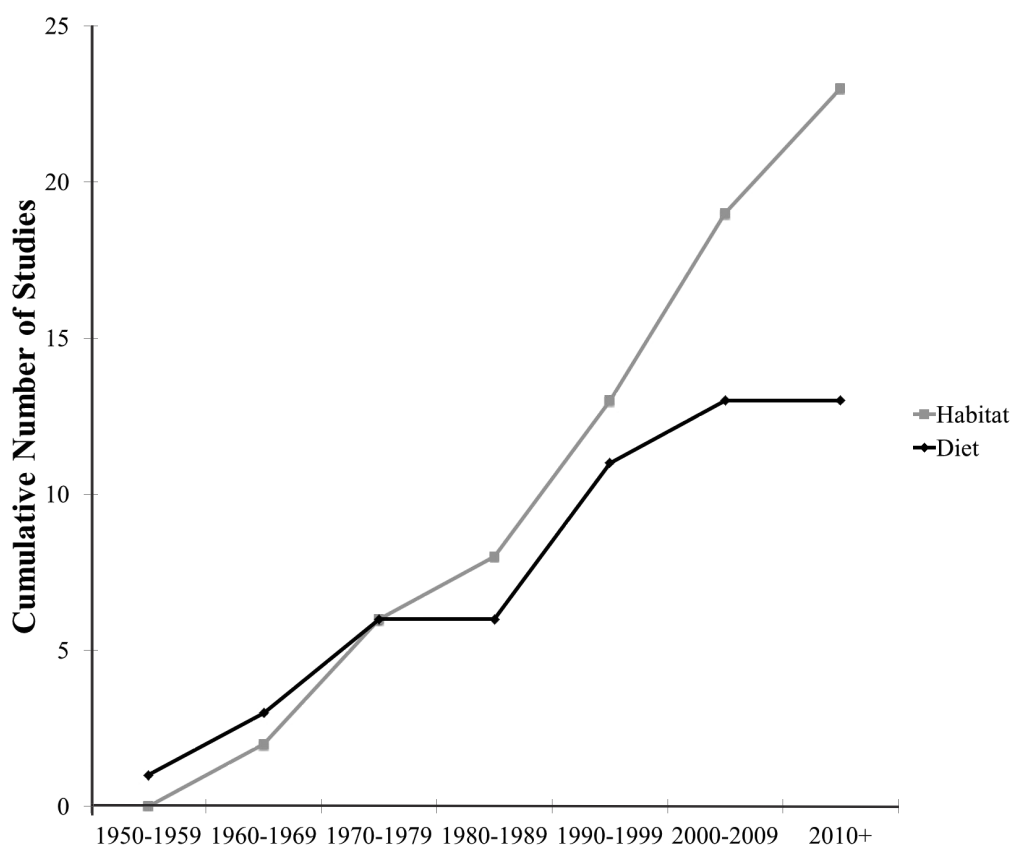

Fig. 2. Cumulative number of Greater Sage-Grouse diet and habitat studies that report data on forbs in big sagebrush plant communities in western North America, 1952 to present. Sources include both journal and nonrefereed articles obtained from the University of Wyoming libraries and Google Scholar.

observational and one experimental study included in this section (Supplementary Material 1). None of these studies had substantially conflicting results (e.g., one result was positive and another result was negative).

SPRING.-Female Greater Sage-Grouse consume a diverse diet in March and April; however, we found no information about male diets in spring or about diet effects on male lekking success. Forbs contain crude protein, calcium, and phosphorus, which contribute to nutritional status and reproductive success of female Greater Sage-Grouse in the spring (Barnett and Crawford 1994, Gregg et al. 2008). In sagebrush communities in Oregon and Nevada, adult females ate 21-22 different food items, of which 15-16 were different forb species (Supplementary Material 2; Barnett and Crawford 1994, Gregg et al. 2008). Females commonly consumed species in the Asteraceae, Fabaceae, Polemoniaceae, and Ranunculaceae families (Supplementary Material 2; Barnett and Crawford 1994, Gregg 2006, Gregg et al. 2008). Genera commonly consumed were Agoseris Raf., Antennaria Gaertn., Arabis L., Astragalus L., Collinsia Nutt., Crepis L., Delphinium L., Eriogonum
Michx., Lomatium Raf., Phlox L., Ranunculus L., and Trifolium L. (Supplementary Material 2). In Oregon, forbs were found in $89 \%$ of females' crop dissections and contributed up to $35.6 \%$ of the aggregate dry mass (Gregg et al. 2008). In another study, forbs contributed up to $50 \%$ of the weight of the spring diet (Barnett and Crawford 1994). Less than $1 \%$ of the weight consumed was grass (Barnett and Crawford 1994).

SUMMER.-Chicks hatch in late spring (Schroeder 1997) and need access to forbs, which are more palatable than sagebrush in summer (Rosentreter 2004). In summer, both adult and juvenile Greater Sage-Grouse consume forbs (Patterson 1952, Klebenow and Gray 1968, Klebenow 1969, Martin 1970, Peterson 1970, Wallestad and Eng 1975, Pyle 1993, Drut et al. 1994b). One study in Oregon found that juveniles consumed 41 invertebrate families, 34 forb genera, and 3 grass and shrub genera (Drut et al. 1994b). In big sagebrush communities in Idaho, Oregon, and Montana, adults and juveniles consumed species in the families Asteraceae, Brassicaceae, Fabaceae, Liliaceae, and Polemoniaceae in mountain big sagebrush and Wyoming big sagebrush 
(Supplementary Material 2; Patterson 1952, Klebenow and Gray 1968, Klebenow 1969, Martin 1970, Peterson 1970, Wallestad and Eng 1975, Pyle 1993, Drut et al. 1994b). Genera commonly consumed were Achillea L., Agoseris, Astragalus, Lactuca L., Taraxacum F.H. Wigg., and Trifolium (Supplementary Material 2). Some forb taxa had all aboveground parts consumed, such as some species in Asteraceae; whereas other forb species had only their reproductive parts consumed, such as some species in Liliaceae (Klebenow and Gray 1968, Peterson 1970). The seasonal timing of the consumption of forb species was likely related to plant phenology or relative availability; for example, pepperweed (Lepidium L.) pods were low to the ground and thus eaten by juveniles (Klebenow and Gray 1968, Peterson 1970).

Arthropods are also an important food source for both adults and juveniles in the summer. As many as 41 invertebrate taxa were consumed primarily from the orders Coleoptera (beetles), Hymenoptera (ants), and Orthoptera (grasshoppers) in Idaho (Klebenow and Gray 1968), Montana (Martin 1970, Peterson 1970, Wallestad and Eng 1975), and Oregon (Drut et al. 1994b). In one experiment, captive-born juvenile Greater Sage-Grouse $\leq 10$ days old that were denied a diet containing insects had a $100 \%$ mortality rate, whereas no juvenile chicks in the control group (i.e., those fed a diet including insects and forbs) died during the first 10 days (Johnson and Boyce 1990). An additional study in Montana found that juveniles consumed more Orthoptera during the summer when forbs dried up earlier (Peterson 1970).

FALL AND WinTER.-In the fall, the Greater Sage-Grouse diet transitions from forbs and insects to big sagebrush foliage (Patterson 1952, Wallestad and Eng 1975, Schroeder et al. 1999). In October and November, adult Greater Sage-Grouse in Montana were observed consuming forbs from the Asteraceae and Fabaceae families, but no insects (Wallestad and Eng 1975). In Montana and Wyoming during December, January, and February, they fed primarily on sagebrush (Patterson 1952, Wallestad and Eng 1975), especially Wyoming big sagebrush in Colorado (Remington and Braun 1985) and black sagebrush in Idaho (Frye et al. 2013).

\section{Habitat}

Greater Sage-Grouse use forbs as cover for life stages including lekking, nesting, and brood rearing. We identified a total of 23 habitat studies, of which 8 were from the Journal of Wildlife Management (Fig. 1) and 15 (65\%) were from the 1990s or later (Fig. 2). Habitat studies were based on 22 observational studies and 1 experimental study (Supplementary Material 1), and 7 of these studies had conflicting results.

LEKKING AND NesTing.-Forbs provide herbaceous cover at nesting sites for Greater Sage-Grouse. Forb cover is important because it positively influences nest success, most likely by decreasing nest visibility to predators (Watters et al. 2002). Forb cover at nesting sites from 24 studies ranged from approximately $1 \%$ to $21 \%$, and grass cover ranged from approximately $3 \%$ to $58 \%$ (Hagen et al. 2007). However, Hagen et al. (2007) is a metaanalysis paper and therefore synthesized many different studies with different methods, which likely explains why there was high variability in reported forb and grass cover values. One study suggested that, although both grass and forb cover contributed to nest success, forb cover contributed to success more than grass cover and success could increase by $4 \%$ with an $8 \%-11 \%$ increase in forb cover in southeastern Alberta (Watters et al. 2002). By comparison, highest nest success is correlated with greater grass height and shrub cover in the eastern portion of Greater Sage-Grouse range where sagebrush is patchier than in areas in the central and western portion of Greater Sage-Grouse range (Herman-Brunson et al. 2009, Doherty et al. 2011, 2014).

Greater Sage-Grouse select a variety of shrubs and forbs at lekking and nesting sites. Also, Greater Sage-Grouse select nesting sites with more visual obstruction than random locations (Dinkins et al. 2016). At a lekking site in Nevada, tall tumblemustard (Sisymbrium altissimum L.), an introduced annual/ biennial, averaged $0.5 \mathrm{~m}$ in height (Giezentanner and Clark 1974); and in Wyoming, average visibility from a cover board was $80.2 \%$ and forb species richness was approximately 7 (Klott and Lindzey 1989). At nesting sites in Alberta, Idaho, Oregon, Washington, and Wyoming, females used areas dominated by big sagebrush, threetip sagebrush (Artemisia 
tripartita Rydb.), little sagebrush (Artemisia arbuscula Nutt.), silver sagebrush (Artemisia cana Pursh.), and occasionally dead residual plants and other cover such as large forbs (Klebenow 1969, Gregg 1992, Apa 1998, Sveum et al. 1998, Aldridge and Brigham 2002, Kirol et al. 2012). Forb families found in the understory near nesting sites in Idaho, Oregon, Utah, and Washington included Asteraceae, Chenopodiaceae, and Fabaceae (Supplementary Material 2; Klebenow 1969, Gregg 1992, Apa 1998, Sveum et al. 1998, Bunnell et al. 2004). In mountain big sagebrush communities in Utah, forb species diversity averaged $>2$ species per $0.25 \mathrm{~m}^{2}$ at nesting sites compared to nearby sites that were not selected for nesting (Bunnell et al. 2004).

BROOD REARING.-Forb cover is important to Greater Sage-Grouse, both directly for providing brood-rearing habitat and indirectly for hosting arthropods which are consumed by Greater Sage-Grouse broods. In mountain big sagebrush and Wyoming big sagebrush communities in Oregon and Nevada, presence of a single Lepidopteran species (i.e., butterflies and moths) decreased the likelihood of losing an entire brood by $11.8 \%$; and as each percentage point in the frequency of Phlox spp. increased at brood-rearing sites, the likelihood of losing an entire brood decreased by 2.7\% (Gregg and Crawford 2009). Moreover, in Wyoming, abundance of medium-sized Coleoptera and Hymenoptera was moderately $(r=0.68)$ to strongly $(r=0.81)$ correlated with total forb cover in Wyoming big sagebrush communities (Thompson et al. 2006), although the relationship between forb cover and arthropod presence is not always positive for all orders of arthropods and may depend on whether there are mainly broad-leaf or cushion forbs present (Schreiber et al. 2015). These different conclusions may result from differing methodology, since Thompson et al. (2006) grouped all forbs together in their models, whereas Schreiber et al. (2015) separated forbs in their models by characteristics such as leaf type. Woodward et al. (2011) found that although approximately one-third of initial nests failed, over half of re-nesting female Greater Sage-Grouse were successful in a year when herbaceous cover was higher than in previous years.

During brood rearing, Greater SageGrouse inhabit sagebrush (8 studies), bitter- brush (1 study), greasewood (2 studies), grassland (1 study), alfalfa fields (Medicago sativa L.; 1 study), lakebeds/meadows (1 study), and ditches (1 study); and many of these studies found that Greater Sage-Grouse use multiple vegetation types (Klebenow 1969, Peterson 1970, Wallestad 1971, Drut et al. 1994a, Apa 1998, Aldridge and Brigham 2002, Thompson et al. 2006, Kirol et al. 2012). Plant families found in brood-rearing habitat include Asteraceae, Fabaceae, and Polygonaceae (Supplementary Material 2; Klebenow 1969, Peterson 1969, Martin 1970, Wallestad 1971, Dunn and Braun 1986, Klott and Lindzey 1990, Apa 1998, Bunnell et al. 2004, Gregg and Crawford 2009). Genera included Achillea, Astragalus, Lupinus L., Polygonum L., and Taraxacum (Supplementary Material 2). If forbs are already abundant, then broods remain at higher elevations (Wallestad 1971, Aldridge and Brigham 2002). However, Klebenow (1969) found that $53 \%$ of broods had dispersed to bitterbrush communities by July. Peterson (1970) found that $50 \%$ of broods inhabited lower-elevation greasewood or grassland vegetation types in September. Wallestad (1971) found that by July and August, broods occupied approximately 58 ha of alfalfa field and approximately 37 ha of greasewood. Fischer et al. (1996b) found that there was a strong negative correlation $(r=-0.83)$ between Greater Sage-Grouse migrations and vegetal moisture. Daily movements of broods may also be related to forb cover. For example, broods preferred areas with significantly $(P<0.05)$ lower horizontal cover during the early and late parts of the day in Colorado, Wyoming, and Utah (Dunn and Braun 1986).

Several studies indicated that broods may select areas with higher forb cover and diversity. Bunnell et al. (2004) found that forb diversity at brood sites averaged 3 species per $0.25 \mathrm{~m}^{2}$ compared to 2 species per $0.25 \mathrm{~m}^{2}$ at available sites. At brood sites in Oregon, Drut et al. (1994a) found that forb cover varied from $10 \%$ to $27 \%$ during early brood rearing (Drut et al. 1994a); while in Montana, forb canopy cover averaged between $17 \%$ and $27 \%$, with yellow sweetclover (Melilotus officinalis L. Lam.) contributing $10 \%-12 \%$ of the total forb cover (Wallestad 1971). We found 2 studies where the selection effect for forb cover was negligible between brood and random sitesin Alberta (11.2\% vs. $12.6 \%$; Aldridge and 
Brigham 2002) and in Wyoming (food forbs: $6.7 \%$ vs. $5.9 \%$; total forb cover $7.5 \%$ vs. $7.1 \%$; Kirol et al. 2012). Aldridge and Brigham (2002) suggest that their results may be due to the amount of precipitation in the area combined with a lack of lowland areas, resulting in little difference between forb abundance values. Kirol et al. (2012) also had similar average forb cover at random plots and broodrearing locations. Wallestad (1971) did not specify forb cover values for the surrounding area, and Bunnell et al. (2004) and Drut et al. (1994a) stated that forb cover differed between used habitat and the surrounding area.

\section{Rangeland Management Practices}

Livestock GrazinG.-Livestock grazing is prevalent in big sagebrush communities, and the effects of grazing are important because an estimated $99 \%$ of sagebrush communities have been grazed at some point (West 1996). Although the 7 grazing studies we identified are not experimental research (Supplementary Material 1), there are no conflicting results. The lack of experimental studies on this subject has been recognized before, such as by Miller et al. (1994), though these researchers did conclude that grazing results in both indirect and direct losses of perennial forbs. Beck and Mitchell (2000) in their review paper also called for more experimental studies to investigate the effects of grazing on forbs. Grazing may cause the understory of sagebrush communities to change from being dominated by native grasses to being dominated by invasive grasses (Branson 1985), such as cheatgrass (Bromus tectorum L.; Young and Allen 1997); and in some areas, invasive plants have been introduced to increase forage for grazers (Boyd et al. 2014). Several studies have documented that increases in invasive species and decreases in native grasses have resulted in negative impacts for forbs. Davies (2011) found that approximately $15 \%$ of variation in perennial forb biomass and $19 \%$ of variation in perennial forb cover was explained by medusahead (Taeniatherum caput-medusae L. Nevski) in Wyoming big sagebrush communities in southeastern Oregon, while Parkinson et al. (2013) found that the relative growth rate of native forb shoots decreased by $45 \%$ to $81 \%$ when forbs such as hoary aster (Machaeranthera canescens Pursh A. Gray), Munro's globemallow (Sphaeralcea munroana Douglas
Spach), royal penstemon (Penstemon speciosus Douglas ex Lindl.), and sulphur-flower buckwheat (Eriogonum umbellatum Torr.) were grown with cheatgrass. Furthermore, in mountain big sagebrush communities in Utah, Greater Sage-Grouse avoided grazed areas dominated by smooth brome (Bromus inermis Leyss.), presumably because forb diversity was low (Bunnell et al. 2004). Evans (1986) found that Taraxacum abundance was higher but overall forb diversity was lower in grazed areas in Nevada. One study suggested that Greater Sage-Grouse populations inhabiting heavily grazed mountain big sagebrush communities may have declined because intense grazing reduced grasses and forbs necessary for nesting cover (Pedersen et al. 2003). However, light and rest-rotation grazing in mountain big sagebrush communities may allow forbs to recover, and Taraxacum and Achillea present in lightly grazed areas may be preferred by Greater Sage-Grouse (Neel 1980).

FIRE.-Fire studies in our synthesis are based on 2 experimental and 10 observational studies (Supplementary Material 1) of which 10 studies had conflicting results. Fire is an important disturbance in sagebrush communities, and it affects ecosystem functioning such as nutrient dynamics and understory composition (Knick et al. 2005). Fire is influenced by factors such as size and density of sagebrush, presence of cheatgrass, and climate (Baker 2013). Forb responses to fire may differ between Wyoming big sagebrush and mountain big sagebrush communities (Beck et al. 2012) because mountain big sagebrush communities are more resilient to disturbance than Wyoming big sagebrush communities, possibly as a result of growing in conditions that are more suitable for plant growth (Chambers et al. 2007, Davies et al. 2011b, 2012a, Chambers et al. 2014). Some forb species have higher postfire survival rates than others. For example, Astragalus purshii Douglas ex Hook. within 2 years of a fall fire had seedling survival rates that were double in burned areas compared to unburned areas in Wyoming big sagebrush communities in Oregon (Wirth and Pyke 2003). In addition, fire influences forb abundance differentially across species. In Wyoming big sagebrush communities in Oregon, the density, frequency, and relative abundance of 5 out of 19 forb species significantly decreased within one year after a 
fall fire (Wrobleski and Kauffman 2003). Wrobleski and Kauffman (2003) found that $65 \%$ of Phlox longifolia plants had reproductive structures postburn compared to $45 \%$ of plants in control plots; and $41 \%$ of Modoc hawksbeard (Crepis modocensis Greene) plants had reproductive structures postburn compared to $25 \%$ in control plots. However, other forb species had negative responses to fire in terms of reproduction. For example, Antennaria dimorpha (Nutt.) Torr. \& A. Gray had an approximately $20-\mathrm{cm}^{2}$ smaller crown area per individual, possibly because it was adapted to live in unburned areas (Wrobleski and Kauffman 2003). In contrast, in mountain big sagebrush communities in Oregon, frequency of forbs in the tribe Cichorieae (Asteraceae) significantly increased in burned areas (78\%) compared to control areas (50\%) within 1-2 years after a fall fire (Pyle and Crawford 1996). These results may have differed because, in addition to the studies being conducted at sites with different sagebrush subspecies, Wrobleski and Kauffman (2003) conducted fall burns, whereas Pyle and Crawford (1996) conducted both spring and fall burns. Our synthesis of these results should be interpreted with caution, and more research is needed on how the timing of fire influences forbs in big sagebrush ecosystems.

Forb cover after fire also varies in sagebrush communities. In mountain big sagebrush communities in Oregon, forb cover was $8 \%$ on unburned plots compared to $13 \%-15 \%$ on burned plots (Pyle and Crawford 1996). In Idaho, burning increased forb production by $61 \%$ after an August fire, although this study did not specify sagebrush subspecies (Mueggler and Blaisdell 1958). One study in Montana found that forb cover in Wyoming big sagebrush communities was not different between control and burn plots; forb canopy cover averaged approximately $8 \%$ for both of these areas (Cooper et al. 2011). In Wyoming big sagebrush communities in Montana, Wambolt et al. (2001) reported that there was no significant $(P \leq 0.05)$ change in perennial forb cover in burned sites. Beck et al. (2009) reported that the rate of increase for forb cover and richness was greater in unburned control plots $(0.295$ [SE 0.084] and 0.180 [SE 0.032], respectively) compared to burned sites $(-0.033$ [SE 0.126$]$ and 0.068 [SE 0.024], respectively) in Wyoming big sagebrush communities in southeastern Idaho after an August prescribed fire. Another study found that fall fire did not increase perennial forb cover except for a Phlox sp. in Wyoming big sagebrush communities in Oregon (Bates et al. 2011). In contrast, annual forb cover composed of $90 \%$ pale madwort (Alyssum alyssoides [L.] L.) was 5.2 (SE 1.9) after fire, compared to 0.7 (SE 0.4) in control plots in those same Wyoming big sagebrush communities in Oregon (Bates et al. 2011). Forb cover may have varied between these studies because they were conducted over different time frames: Pyle and Crawford (1996) sampled vegetation within 2 years of burning, Mueggler and Blaisdell (1958) conducted their study within 3 years of burning, Rhodes et al. (2010) sampled vegetation within 6 years of a fall fire, Bates et al. (2011) conducted their study in the 8 years following fire, Beck et al. (2009) conducted their study as much as 14 years after fire, Wambolt et al. (2001) conducted their study between 2 and 32 years after fire, and Cooper et al. (2011) sampled their sites between 4 and 67 years after fire. As such, these results may not be directly comparable.

Fire also affects some arthropods. Burning increased grasshopper abundance 2.3 times in Wyoming big sagebrush sites burned in the 1990s compared to reference sites or sites burned or mowed from 2000 to 2006 in north central Wyoming (Hess and Beck 2014). Fire did not affect ants in Wyoming (Hess and Beck 2014) but did negatively affect ant abundance in Oregon (Rhodes et al. 2010, Bates et al. 2011) and Idaho (Fischer et al. 1996a). While Hess and Beck (2014) conducted their study at sites treated over a wide time period (2-19 years postburn) and had the longest time between burning and sampling, Rhodes et al. (2010), Bates et al. (2011), and Fischer et al. (1996a) sampled insects relatively soon (1-8 years) after fire, which may explain the discrepancy in these results for ants. Fire did not affect beetles in Idaho (Fischer et al. 1996a), Oregon (Pyle and Crawford 1996, Rhodes et al. 2010, Bates et al. 2011), or Wyoming (Hess and Beck 2014).

Chemical and Mechanical Treatments. Chemical and mechanical treatments were examined in 3 observational and 5 experimental studies (Supplementary Material 1), of which 5 had conflicting results. Chemical treatments have been applied to sagebrush 
since the 1940s (Miller and Eddleman 2001) and have had varying effects on forb cover and composition. Tebuthiuron, an herbicide that hinders photosynthesis (Crawford et al. 2004), increased mean forb cover-largely composed of common dandelion (Taraxacum officinale F.H. Wigg.) - from $4 \%$ to $12 \%$ in mountain big sagebrush communities in Utah (Dahlgren et al. 2006). This increase in forb cover may have been due to chemical application which resulted in "sagebrush skeletons" that altered wind and moisture conditions for forbs (Dahlgren et al. 2006). In another study conducted in Wyoming big sagebrush communities in California, native annual forb cover was 6.5 times higher in plots treated with Imazapic (Kyser et al. 2013).

Another chemical treatment, 2,4-D, which causes uncontrolled growth and eventual death in broad-leaf plants, has negative effects on forbs. In a Montana study, forbs contributed about $20 \%$ of canopy cover in the understory, where only $4 \%$ of Greater SageGrouse locations occurred in 2,4-D sprayed strips, whereas forbs in unsprayed strips contributed about $40 \%$ of canopy cover in the understory (Martin 1970). In Idaho, spraying 2,4-D resulted in a 39\% loss of forbs, especially Lupinus spp. and Erigeron L. spp. (Mueggler and Blaisdell 1958). Chemical treatments increased nonnative and annual forb cover in these studies.

Mechanical treatments used to reduce sagebrush cover also affect forbs and arthropods in sagebrush communities. In mountain big sagebrush communities in Utah, Dixie harrow treatments (using a tractor to drag a harrow with welded railroad spikes) increased forb cover from $7.6 \%$ to $10.7 \%$, but there were only slight forb cover increases in plots treated with a Lawson aerator, possibly because more overstory cover was left after treatment (Dahlgren et al. 2006). In Idaho, roto-beating (shredding sagebrush) and railing (using a railroad rail to thin sagebrush) big sagebrush communities with a healthy herbaceous understory increased forb production by $50 \%$ and $20 \%$, respectively, especially for Lupinus spp. (Mueggler and Blaisdell 1958). In Oregon, mowed Wyoming big sagebrush communities had more annual forbs and nonnative grasses (Davies et al. 2011a, 2012b), whereas in Oregon (Davies et al. 2011a) and Wyoming (Hess and Beck 2014) perennial forb abundance did not increase after mowing. Mowing did not increase ant, grasshopper, or beetle abundance in Wyoming (Hess and Beck 2014). Although Dahlgren et al. (2006) reported increases in overall forb abundance, they did not distinguish between annual and perennial forbs when collecting field data, whereas Davies et al. (2011a, 2012b) and Hess and Beck (2014) examined these groups separately. Additionally, Davies et al. (2011a, 2012b) and Hess and Beck (2014) used the same treatment in their methods (mowing), whereas Mueggler and Blaisdell (1958) used rotobeating and railing as their methods for studying plant responses.

\section{Temperature and Precipitation}

Temperature and precipitation studies included 2 observational and 6 experimental studies. None of these studies had results that conflicted appreciably.

Temperature.-Adler and Hille Ris Lambers (2008) hypothesized that shrub and grass functional groups may fare better under future climate change than forbs because shrubs and grasses occur in higher densities than forbs. Increased temperatures will likely cause snowmelt to occur sooner (Harte and Shaw 1995, Price and Waser 1998, Palmquist et al. 2016), with important implications for forb species because timing of snowmelt and winter precipitation influences forb phenology (Price and Waser 1998, Inouye 2008). Warmer temperatures can cause forb species to emerge sooner and die later (e.g., Munro's globemallow, Sphaeralcea munroana Douglas Spach, and Lewis flax, Linum lewisii Pursh), emerge sooner and die sooner (e.g., Palmer's penstemon, Penstemon palmeri A. Gray), or have lower emergence and higher mortality rates (e.g., tapertip hawksbeard, Crepis acuminata Nutt.; Whitcomb 2011). Forbs in heated plots in Colorado had significantly less aboveground biomass in $1993(P=0.001)$ and $1994(P=$ 0.004 ) when snowmelt occurred earlier (Harte and Shaw 1995). Another study found negative responses to warming in several species. For example, the number of larkspur (Delphinium L.) in control plots was 4.6 individuals . $\mathrm{m}^{-2}$ compared to 1.3 individuals $\cdot \mathrm{m}^{-2}$ in heated plots (de Valpine and Harte 2001). In addition, the reproductive parts of Erigeron, Delphinium, and Helianthella (Helianthella Torr. \& A. Gray) plants are susceptible to 
frost damage (Inouye 2008). One experiment documented positive responses of warming for 3 genera: Helianthella because it experienced less frost damage, Eriogonum because it had larger flowering stalks, and cinquefoil (Potentilla L.) because it exhibited increases in aboveground biomass (de Valpine and Harte 2001). Therefore, although these studies overall suggest that warming may decrease the biomass of some common forb genera (except Potentilla), there may be less damage to forb genera than expected from frost.

Precipitation.-Precipitation affects forbs in big sagebrush communities because these communities are already water limited. Longterm studies in basin big sagebrush and Wyoming big sagebrush communities indicated that although forb density fluctuated over 60 years, extreme drought may result in increased mortality of perennial forbs (Anderson and Inouye 2001). In an experiment conducted in a Wyoming big sagebrush community in Oregon, areas with shallow soils that were given precipitation treatments in the winter and spring had similar soil water content, but in 1999 perennial forbs in the spring precipitation treatments had less biomass (approximately $20 \mathrm{~kg} \cdot \mathrm{ha}^{-1} \mathrm{vs} .60 \mathrm{~kg} \cdot \mathrm{ha}^{-1}$ ) and cover (approximately 2\% vs. 8\%) than those in the winter precipititaion treatements, suggesting that the timing of precipitation may be important to forbs (Bates et al. 2006). In another experiment in Idaho, Tragopogon dubius seedling survival by August 2007 was higher in control plots (approximate $\bar{x}=60 \%$ ) than plots with shelter from winter precipitation (approximate $\bar{x}=18 \%$; Prevéy et al. 2010). Overall, the existing literature suggests that native forbs have low resilience to changes in precipitation patterns in big sagebrush communities.

\section{Knowledge Gaps and Research Needs}

Our analysis uncovered 3 important uncertainties and research needs. First, information about forbs was reported at the functional type level or genus in many studies. Second, information about forbs at lekking sites and male Greater Sage-Grouse was limited. Third, the data linking forbs and temperature/precipitation were sparse.

Many studies focused their measurements on the dynamics of shrubs and graminoids, while information about forbs was vague or incomplete. Many diet or habitat studies grouped forbs together as a single functional group, despite forbs having a high diversity of traits (e.g., Wallestad 1971, Dunn and Braun 1986, Klott and Lindzey 1989, Drut et al. 1994a, Sveum et al. 1998, Schroeder et al. 1999, Aldridge and Brigham 2002, Watters et al. 2002, Thompson et al. 2006, Hagen et al. 2007, Beck et al. 2009, Woodward et al. 2011, Kirol et al. 2012, Schreiber et al. 2015). Other diet or habitat studies included information to the family or genus level but did not identify most or all forbs to the species level (e.g., Patterson 1952, Gregg 1992, Barnett and Crawford 1994, Drut et al. 1994b, Gregg and Crawford 2009).

Only 3 of 13 diet studies and 2 of 23 habitat studies discussed the importance of forbs for Greater Sage-Grouse during lekking (Giezentanner and Clark 1974, Klott and Lindzey 1989, Barnett and Crawford 1994, Gregg 2006, Gregg et al. 2008), and they focused mostly on females. Leks are important because they are where breeding and summer life stage activities mostly take place (Wallestad and Schladweiler 1974, Schroeder et al. 1999). Therefore, more information is needed about the role of forbs at lekking sites.

We found very little information about the relationship between forbs and temperature/ precipitation. More literature was available about the effects of rangeland management practices on forbs than the effects of changes in temperature/precipitation on forbs, especially for sagebrush communities. This lack of information limits our ability to understand the potential responses of forbs to climate change in these communities. Although Dumroese et al. (2015) reported information about the importance of forbs and arthropods in the diet and habitat of Greater Sage-Grouse and the relationship between forbs and some rangeland management practices, to our knowledge, this paper is the first to bring all of these components, as well as temperature and precipitation, together. This topic is an important research need because models suggest that future climate changes will likely affect sagebrush communities (Homer et al. 2015).

Overall, we conclude that there is wide agreement among Greater Sage-Grouse biologists that forbs are an important diet and habitat component. However, our knowledge about forbs in sagebrush communities is limited 
and additional research is needed to fill key knowledge gaps.

\section{Supplementary Material}

Two online-only supplementary files accompany this article (scholarsarchive.byu.edu/ wnan/vol76/iss3/6).

Supplementary Material 1. Observational and experimental studies by section for forbs used by Greater Sage-Grouse: diet, habitat, the relationship of forbs to rangeland management practices, and the relationship of forbs to temperature and precipitation. Sources were obtained from searches through Web of Science (Thomson Reuters) and Google Scholar.

Supplementary Material 2. Forbs found in Greater Sage-Grouse diet and habitat studies in big sagebrush plant communities. Information was obtained from sources searched through Web of Science (Thomson Reuters) and Google Scholar.

\section{ACKNOWLEDGMENTS}

We thank the U.S. Geological Survey North Central Climate Science Center (grant G12AC 20504), the U.S. Fish and Wildlife Service (F13AC00865), and the University of Wyoming for financial support. We also thank 2 anonymous reviewers whose input improved an earlier version of this manuscript. Any use of trade, product, or firm names is for descriptive purposes only and does not imply endorsement by the U.S. government.

\section{Literature Cited}

Adler, P.B., And J. Hille Ris Lambers. 2008. The influence of climate and species composition on the population dynamics of ten prairie forbs. Ecology 89:3049-3060

Aldridge, C.L., AND R.M. Brigham. 2002. Sage-grouse nesting and brood habitat use in southern Canada. Journal of Wildlife Management 66:433-444.

Aldridge, C.L., AND R.M. Brigham. 2003. Distribution, abundance, and status of the Greater Sage-Grouse, Centrocercus urophasianus, in Canada. Canadian Field-Naturalist 117:25-34.

Anderson, J.E., AND R.S. InOuYE. 2001. Landscape-scale changes in plant species abundance and biodiversity of a sagebrush steppe over 45 years. Ecological Monographs 71:531-556.

APA, A.D. 1998. Habitat use and movements of sympatric sage and Columbian sharp-tailed grouse in southeastern Idaho. Doctoral dissertation, University of Idaho, Moscow, ID.

Apostol, D., and M. Sinclair. 2006. Restoring the Pacific Northwest: the art and science of ecological restoration in Cascadia. Island Press, Washington, DC.
BAKER, W.L. 2013. Is wildland fire increasing in sagebrush landscapes of the western United States? Annals of the Association of American Geographers 103:5-19.

BarnetT, J.K., and J.A. Crawford. 1994. Pre-laying nutrition of sage grouse hens in Oregon. Journal of Range Management 47:114-118.

Bates, J.D., E.C. Rhodes, AND K. Davies. 2011. Impacts of fire on sage-grouse habitat and diet resources. Natural Resources and Environmental Issues 27(15): $1-17$.

Bates, J.D., T. Svejar, R.F. Miller, and R.A. Angell. 2006. The effects of precipitation timing on sagebrush steppe vegetation. Journal of Arid Environments 64:670-697.

Beck, J.L., J.W. Connelly, And K.P. ReEse. 2009. Recovery of Greater Sage-Grouse habitat features in Wyoming big sagebrush following prescribed fire. Restoration Ecology 17:393-403.

Beck, J.L., J.W. Connelly, and C.L. Wambolt. 2012. Consequences of treating Wyoming big sagebrush to enhance wildlife habitats. Rangeland Ecology and Management 65:444-455.

Beck, J.L., AND D.L. Mitchell. 2000. Influences of livestock grazing on sage grouse habitat. Wildlife Society Bulletin 28:993-1002.

BECK, T.D.I. 1977. Sage grouse flock characteristics and habitat selection in winter. Journal of Wildlife Management 41:18-26.

Boyd, C.S., J.L. Beck, and J.A. TanaKa. 2014. Livestock grazing and sage-grouse habitat: impacts and opportunities. Journal of Rangeland Applications 1:58-77.

Bradford, J.B., D.R. SchlaEPFER, AND W.K. Lauenroth. 2014. Ecohydrology of adjacent sagebrush and lodgepole pine ecosystems: the consequences of climate change and disturbance. Ecosystems 17:590-605.

Branson, F.A. 1985. Vegetation changes on western ranges. Society for Range Management, Range Monograph Number 2, Denver, CO.

Braun, C.E. 1998. Sage grouse declines in western North America: what are the problems? Proceedings of the Western Association State Fish and Wildlife Agencies 78:139-156.

Bunnell, K.D., J.T. Flinders, D.L. Mitchell, and J.H. WARDER. 2004. Occupied and unoccupied sage grouse habitat in Strawberry Valley, Utah. Journal of Rangeland Management 57:524-531.

Chambers, J.C., B.A. Bradley, C.S. Brown, C. D’Antonio, M.J. Germino, J.B. Grace, S.P. Hardegree, R.F. Miller, AND D.A. PyKe. 2014. Resilience to stress and disturbance, and resistence to Bromus tectorum L. invasion in cold desert shrublands of western North America. Ecosystems 17:360-375.

Chambers, J.C., B.A. Roundy, R.R. Blank, S.E. Meyer, AND A. WhitTaker. 2007. What makes Great Basin sagebrush ecosystems invasible by Bromus tectorum? Ecological Monographs 77:117-145.

Coates, P.S., M.A. Ricca, B.G. Prochazka, K.E. Doherty, M.L. BRooks, and M.L. CasazZa. 2015. Long-term effects of wildfire on Greater Sage-Grouse-integrating population and ecosystem concepts for management in the Great Basin. U.S. Geological Survey Open-File Report 2015-1165. 42 pp.

Connelly, J.W., and C.E. Braun. 1997. Long-term changes in sage grouse Centrocercus urophasianus populations in western North America. Wildlife Biology 3:229-234. 
Connelly, J.W., S.T. Knick, M.A. Schroeder, And S.J. Stiver. 2004. Conservation assessment of Greater Sage-Grouse and sagebrush habitats. Unpublished Report, Western Association of Fish and Wildlife Agencies, Cheyenne, WY.

Connelly, J.W., M.A. Schroeder, A.R. Sands, and C.E. Braun. 2000. Guidelines to manage sage grouse populations and their habitats. Wildlife Society Bulletin 28:967-985.

Cooper, S.V., P. Lesica, and G.M. Kudray. 2011. Postfire recovery of Wyoming big sagebrush steppe in central and southeast Montana. Natural Resources and Environmental Issues 16(12):1-9.

Crawford, J.A., R.A. Olson, N.E. West, J.C. Mosley, M.A. Schroeder, T.D. Whitson, R.F. Miller, M.A. GREGG, AND C.S. BoYd. 2004. Ecology and management of sage-grouse and sage-grouse habitat. Journal of Range Management 57:2-19.

Dahlgren, D.K., R. Chi, and T.A. Messmer. 2006. Greater Sage-Grouse response to sagebrush management in Utah. Wildlife Society Bulletin 34:975-985.

Daubenmire, R. 1966. Vegetation: identification of typal communities. American Association for the Advancement of Science 151:291-298.

Davies, G.M., J.D. Baker, E. Dettweiler-Robinson, P.W. Dunwiddie, S.A. Hall, J. Downs, and J. Evans. 2012a. Trajectories of change in sagebrush steppe vegetation communities in relation to multiple wildfires. Ecological Applications 22:1562-1577.

DAVIES, K.W. 2011. Plant community diversity and native plant abundance decline with increasing abundance of an exotic annual grass. Oecologia 167:481-491.

Davies, K.W., J.D. Bates, And A.M. Nafus. 201la. Are there benefits to mowing Wyoming big sagebrush plant communities? An evaluation in southeastern Oregon. Environmental Management 48:539-546.

Davies, K.W., J.D. Bates, and A.M. Nafus. 2012b. Mowing Wyoming big sagebrush communities with degraded herbaceous understories: has a threshold been crossed? Rangeland Ecology and Management 65:498-505.

Davies, K.W., C.S. Boyd, J.L. Beck, J.D. Bates, T.J. Svejcar, and M.A. Gregg. 2011b. Saving the sagebrush sea: an ecosystem conservation plan for big sagebrush plant communities. Biological Conservation 144:2573-2584.

de Valpine, P., and J. Harte. 2001. Plant responses to experimental warming in a montane meadow. Ecology 82:637-648.

Dinkins, J.B., K.T. Smith, J.L. Beck, C.P. Kirol, A.C. Pratt, and M.R. Conover. 2016. Microhabitat conditions in Wyoming's sage-grouse core areas: effects on nest site selection and success. PLOS ONE 11:e0150798.

Doherty, K.E., J.L. Beck, And D.E. Naugle. 2011. Comparing ecological site descriptions to habitat characteristics influencing Greater Sage-Grouse nest site occurrence and success. Rangeland Ecology and Management 64:344-351.

Doherty, K.E., D.E. Naugle, J.D. Tack, B.L. Walker, J.M. GRAHAM, AND J.L. BECK. 2014. Linking conservation actions to demography: grass height explains variation in Greater Sage-Grouse nest survival. Wildlife Biology 20:320-325.

Drut, M.S., J.A. Crawford, and M.A. Gregg. 1994a. Brood habitat use by sage grouse in Oregon. Great Basin Naturalist 54:170-176.
Drut, M.S., W.H. Pyle, and J.A. Crawford. 1994b. Diets and food selection of sage grouse chicks in Oregon. Journal of Rangeland Management 47:90-93.

Dumroese, R.K., T. Luna, B.A. Richardson, F.F. KilKenny, AND J.B. RunYon. 2015. Conserving and restoring habitat for Greater Sage-Grouse and other sagebrush obligate wildlife: the crucial link of forbs and sagebrush diversity. Native Plants Journal 16: 276-299.

Dunn, P.O., and C.E. Braun. 1986. Summer habitat use by adult female and juvenile sage grouse. Journal of Wildlife Management 50:228-235.

ENG, R.L., AND P. SCHLADWEILER. 1972. Sage grouse winter movements and habitat use in central Montana. Journal of Wildlife Management 36:141-146.

Evans, C.C. 1986. The relationship of cattle grazing to sage grouse use of meadow habitat on Sheldon National Wildlife Refuge. Master's thesis, University of Nevada, Reno, NV.

Evans, E.W. 1984. Fire as a natural disturbance to grasshopper assemblages of tallgrass prairie. Oikos 43:9-16.

Fischer, R.A., K.P. Reese, and J.W. Connelly. 1996a. An investigation on fire effects within xeric sage grouse brood habitat. Journal of Rangeland Management 49:194-198.

Fischer, R.A., K.P. Reese, and J.W. Connelly. 1996b. Influence of vegetal moisture content and nest fate on timing of female sage grouse migration. Condor 98:868-872.

Frye, G.G., J.W. Connelly, D.D. Musil, and J.S. Forbey. 2013. Phytochemistry predicts habitat selection by an avian herbivore at multiple spatial scales. Ecology 94:308-314.

Giezentanner, K.I., and W.H. Clark. 1974. The use of western harvester ant mounds as strutting locations by sage grouse. Condor 76:218-219.

GregG, M.A. 1992. Use and selection of nesting habitat by sage-grouse in Oregon. Master's thesis, Oregon State University, Corvallis, OR.

GregG, M.A. 2006. Greater Sage-Grouse reproductive ecology: Linkages among habitat resources, maternal nutrition, and chick survival. Doctoral dissertation, Oregon State University, Corvallis, OR.

Gregg, M.A., J.K. Barnett, and J.A. Crawford. 2008. Temporal variation in diet and nutrition of preincubating Greater Sage-Grouse. Rangeland Ecology and Management 61:535-542.

Gregg, M.A., and J.A. Crawford. 2009. Survival of Greater Sage-Grouse chicks and broods in the northern Great Basin. Journal of Wildlife Management 73:904-913.

Hagen, C.A., J.W. Connelly, and M.A. Schroeder. 2007. A meta-analysis of Greater Sage-Grouse Centrocercus urophasianus nesting and brood-rearing habitats. Wildlife Biology 13:42-50.

Harte, J., and R. Shaw. 1995. Shifting dominance within a montane vegetation community: results of a climate-warming experiment. Science 267:876-880.

Herman-Brunson, K.M., K.C. Jensen, N.W. Kaczor, C.C. Swanson, M.A. Rumble, and R.W. Klaver. 2009. Nesting ecology of Greater Sage-Grouse Centrocercus urophasianus at the eastern edge of their historic distribution. Wildlife Biology 15:395-404.

Hess, J.E., AND J.L. BECK. 2012. Burning and mowing Wyoming big sagebrush: do treated sites meet minimum guidelines for Greater Sage-Grouse breeding habitats? Wildlife Society Bulletin 36:85-93. 
Hess, J.E., AND J.L. BECK. 2014. Forb, insect, and soil response to burning and mowing Wyoming big sagebrush in Greater Sage-Grouse breeding habitat. Environmental Management 53:813-822.

Holloran, M.J., B.C. Fedy, And J. DahlKe. 2015. Winter habitat use of Greater Sage-Grouse relative to activity levels at natural gas well pads. Journal of Wildlife Management 79:630-640.

Homer, C.G., G. Xian, C.L. Aldridge, D.K. Meyer, T.R. LOVELAND, AND M.S. O'DONNELL. 2015. Forecasting sagebrush ecosystem components and Greater SageGrouse habitat for 2050: learning from past climate patterns and Landsat imagery to predict the future. Ecological Indicators 55:131-145.

INOUYE, D.W. 2008. Effects of climate change on phenology, frost damage, and floral abundance of montane wildflowers. Ecology 89:353-362.

[IPCC] Intergovernmental Panel on Climate Change. 2013. Summary for policymakers. In: T.F. Stocker, D. Qin, G.-K. Plattner, M. Tignor, S.K. Allen, J. Boschung, A. Nauels, Y. Xia, V. Bex, P.M. Midgley, editors, Climate change 2013: the physical science basis: contribution of Working Group I to the Fifth Assessment Report of the Intergovernmental Panel on Climate Change. Cambridge University Press.

Johnson, G.D., And M.S. Boyce. 1990. Feeding trials with insects in the diet of sage grouse chicks. Journal of Wildlife Management 54:89-91.

Kirol, C.P., J.L. Beck, J.B. Dinkins, and M.R. Conover. 2012. Microhabitat selection for nesting and broodrearing by the Greater Sage-Grouse in xeric big sagebrush. Condor 114:75-89.

Kirol, C.P., J.L. Beck, S.V. Huzurbazar, M.J. Holloran, AND S.N. Miller. 2015. Identifying Greater SageGrouse source and sink habitats for conservation planning in an energy development landscape. Ecological Applications 25:968-990.

KLEBENOW, D.A. 1969. Sage grouse nesting and brood habitat in Idaho. Journal of Wildlife Management 33:649-662.

KLebenow, D.A., and G.M. Gray. 1968. Food habits of juvenile sage grouse. Journal of Range Management 21:80-83.

Klos, P.Z., T.E. Link, and J.T. Abatzoglou. 2014. Extent of the rain-snow transition zone in the western U.S. under historic and projected climate change. Geophysical Research Letters 41:4560-4568.

KLOTT, J.H., AND F.G. LinDZEY. 1989. Comparison of sage and Sharp-Tailed Grouse leks in south central Wyoming. Great Basin Naturalist 49:275-278.

Klott, J.H., AND F.G. Lindzey. 1990. Brood habitats of sympatric sage grouse and Columbian Sharp-Tailed Grouse in Wyoming. Journal of Wildlife Management 54:84-88.

Knick, S.T., D.S. Dobkin, J.T. Rotenberry, M.A. Schroeder, W.M. Vander Haegen, and C. Van RIPER. 2003. Teetering on the edge or too late? Conservation and research issues for avifauna of sagebrush habitats. Condor 105:611-634.

Knick, S.T., A.L. Holmes, and R.F. Miller. 2005. The role of fire in structuring sagebrush habitats and bird communities. Studies in Avian Biology 30:63-75.

Kyser, G.B., R.G. Wilson, J. Zhang, and J.M. DiTomaso. 2013. Herbicide-assisted restoration of Great Basin sagebrush steppe infested with medusahead and downy brome. Rangeland Ecology and Management 66:588-596.
Manier, D.J., D.J.A. Wood, Z.H. Bowen, R.M. Donovan, M.J. Holloran, L.M. Juliusson, K.S. Mayne, S.J. Oyler-McCance, F.R. Quamen, D.J. Saher, and A.J. Titolo. 2013. Summary of science, activities, programs, and policies that influence the rangewide conservation of Greater Sage-Grouse (Centrocercus urophasianus). U.S. Geological Survey Open-File Report 2013-1098, Reston, VA. 170 pp.

Martin, N.S. 1970. Sagebrush control related to habitat and sage grouse occurrence. Journal of Wildlife Management 34:313-320.

Miller, R.F., and L.L. Eddleman. 2001. Spatial and temporal changes of sage grouse habitat in the sagebrush biome. Bulletin 151, Agricultural Experiment Station, Oregon State University, Corvallis, OR.

Miller, R.F., T.J. SvejCAR, AND N.E. West. 1994. Implications of livestock grazing in the intermountain sagebrush region: plant composition. Pages 101146 in M. Vavra, W.A. Laycock, and R.D. Pieper, editors, Ecological implications of livestock herbivory in the West. Society for Range Management, Denver, CO.

Mueggler, W.F., and J.P. Blaisdell. 1958. Effects on associated species of burning, rotobeating, spraying, and railing sagebrush. Journal of Range Management 11:61-66.

NatureServe. 2015. NatureServe Explorer: an online encyclopedia of life [web application]. Version 7.1. NatureServe, Arlington, Virginia; [accessed 16 December 2015]. Available from: http://www.explorer.nature serve.org

NEEL, L.A. 1980. Sage grouse response to grazing management in Nevada. Master's thesis, University of Nevada, Reno, NV.

Nelle, P.A., K.P. Reese, And J.W. Connelly. 2000. Longterm effects of fire on sage grouse habitat. Journal of Range Management 53:586-591.

Palmquist, K.A., D.R. Schlaepfer, J.B. Bradford, and W.K. Lauenroth. 2016. Mid-latitude shrub steppe plant communities: climate change consequences for soil water resources. Ecology 97:2342-2354.

Parkinson, H., C. Zabinski, and N. Shaw. 2013. Impact of native grasses and cheatgrass (Bromus tectorum) on Great Basin forb seedling growth. Rangeland Ecology and Management 66:174-180.

Patterson, R.L. 1952. The sage grouse in Wyoming. Wyoming Game and Fish Commission. Sage Books. Denver, CO.

Pedersen, E.K., J.W. Connelly, J.R. Hendrickson, and W.E. GRANT. 2003. Effect of sheep grazing and fire on sage grouse populations in southeastern Idaho. Ecological Modelling 165:23-47.

Peterson, J.G. 1969. The food habits and summer distribution of juvenile sage grouse in central Montana. Master's thesis, Montana State University, Bozeman, MT.

Peterson, J.G. 1970. The food habits and summer distribution of juvenile sage-grouse in central Montana. Journal of Wildlife Management 34:147-155.

Porter, E.E., AND R.A. RedAK. 1997. Diet of migratory grasshopper (Orthoptera: Acrididae) in a California native grassland and the effect of prescribed spring burning. Environmental Entomology 26:234-240.

Prevéy, J.S., M.J. Germino, N.J. Huntly, and R.S. INOUYE. 2010. Exotic plants increase and native plants decrease with loss of foundation species in sagebrush steppe. Plant Ecology 207:39-51. 
Price, M.V., AND N.M. Waser. 1998. Effects of experimental warming on plant reproductive phenology in a subalpine meadow. Ecology 79:1261-1271.

PyLE, W.H. 1993. Response of brood-rearing habitat of sage grouse to prescribed burning in Oregon. Master's thesis, Oregon State University, Corvallis, OR.

Pyle, W.H., and J.A. Crawford. 1996. Availability of foods of sage grouse chicks following prescribed fire in sagebrush-bitterbrush. Journal of Rangeland Management 49:320-324.

Remington, T.E., and C.E. Braun. 1985. Sage grouse food selection in winter, North Park, Colorado. Journal of Wildlife Management 49:1055-1061.

Rhodes, E.C., J.D. Bates, R.N. Sharp, and K.W. Davies. 2010. Fire effects on cover and dietary resources of sage-grouse habitat. Journal of Wildlife Management 74:755-764.

Rosentreter, R. 2004. Sagebrush identification, ecology, and palatability relative to sage-grouse. Pages 1-14 in N.L. Shaw, M. Pellant, and S.B. Monsen, compilers, Sage-Grouse Habitat Restoration Symposium Proceedings. RMRS-P-38, USDA Forest Service, Rocky Mountain Research Station, Fort Collins, CO.

Schlaepfer, D.R., W.K. Lauenroth, and J.B. Bradford. 2012. Ecohydrological niche of sagebrush ecosystems. Ecohydrology 5:453-466.

Schreiber, L.A., C.P. Hansen, M.A. Rumble, J.J. Millspaugh, R.S. Gamo, J.W. Kehmeier, and N. Wojcik. 2015. Microhabitat selection of brood-rearing sites by Greater Sage-Grouse in Carbon County, Wyoming. Western North American Naturalist 75:348-363.

Schroeder, M.A. 1997. Unusually high reproductive effort by sage grouse in a fragmented habitat in north-central Washington. Condor 99:933-941.

Schroeder, M.A., C.L. Aldridge, A.D. ApA, J.R. Bohne, C.E. Braun, S.D. Bunnell, J.W. Connelly, P.A. Deibert, S.C. Gardner, M.A. Hilliard, et al. 2004. Distribution of sage-grouse in North America. Condor 106:363-376.

Schroeder, M.A., J.R. Young, and C.E. Braun. 1999. Sage grouse (Centrocercus urophasianus). Pages 1-28 in A. Poole and F. Gill, editors, The birds of North America, No. 425. The Birds of North America, Inc., Philadelphia, PA.

Schultz, L. 2012. A pocket guide to sagebrush. Point Reyes Bird Observatory Conservation Science Publication. Petaluma, CA. 85 pp.

Shumar, M.L., AND J.E. Anderson. 1986. Gradient analysis of vegetation dominated by two subspecies of big sagebrush. Journal of Range Management 39:156-160.

SMith, K.T., C.P. KiRol, J.L. BECK, AND F.C. BlOMQUist. 2014. Prioritizing winter habitat for Greater SageGrouse in a landscape influenced by energy development. Ecosphere 5: article 15.

Sveum, C.M., W.D. Edge, and J.A. Crawford. 1998. Nesting habitat selection by sage grouse in southcentral Washington. Journal of Range Management 51:265-269.

Thatcher, A.P. 1959. Distribution of sagebrush as related to site differences in Albany County, Wyoming. Journal of Rangeland Management 12:55-61.

Thompson, K.M., M.J. Holloran, S.J. Slater, J.L. Kuipers, AND S.H. ANDERSON. 2006. Early broodrearing habitat use and productivity of Greater Sage-Grouse in Wyoming. Western North American Naturalist 66:332-342.
USDA, NRCS. 2015. The PLANTS Database. National Plant Data Team, Greensboro, NC; [cited 5 January 2014]. http://plants.usda.gov

[USFWS] United States Fish and Wildlife Service. 2010. Endangered and threatened wildlife and plants: 12-month finding for petitions to list the Greater Sage-Grouse (Centrocercus urophasianus) as threatened or endangered. Federal Register 75:13909-14014.

[USFWS] United States Fish and Wildlife Service. 2015. Endangered and threatened wildlife and plants: 12-month finding on a petition to list Greater Sage-Grouse (Centrocercus urophasianus) as an endangered or threatened species. Federal Register 80:59857-59942.

VALE, T.R. 1974. Sagebrush conversion projects: an element of contemporary environmental change in the western United States. Biological Conservation 6: 274-284.

Wallestad, R.O. 1971. Summer movements and habitat use by sage grouse broods in central Montana. Journal of Wildlife Management 35:129-136.

Wallestad, R., and R.L. Eng. 1975. Foods of adult sage grouse in central Montana. Journal of Wildlife Management 39:628-630.

Wallestad, R., and P. Schladweiler. 1974. Breeding season movements and habitat selection of male sage grouse. Journal of Wildlife Management 38:634-637.

Wambolt, C.L., K.S. Walhof, and M.R. Frisina. 2001. Recovery of big sagebrush communities after burning in southwestern Montana. Journal of Environmental Management 61:243-252.

Watters, M.E., T.L. McLash, C.L. Aldridge, and R.M. BRigham. 2002. The effect of vegetation structure on predation of artificial Greater Sage-Grouse nests. EcoScience 9:314-319.

West, N.E. 1988. Intermountain deserts, shrub steppes, and woodlands. Pages 212-216 in M.G. Barbour and W.D. Billings, editors, North American terrestrial vegetation. Cambridge University Press, U.K.

WEST, N.E. 1996. Strategies for maintenance of and repair of biotic community diversity on rangelands, Pages 326-346 in R.C. Szaro and D.W. Johnston, editors, Biodiversity in managed landscapes: theory and practice. Oxford University Press, New York, NY.

Wнiтсомв, H.L. 2011. Temperature increase effects on sagebrush ecosystem forbs: experimental evidence and range manager perspectives. Master's thesis, Utah State University Logan, UT.

Wirth, T.A., AND D.A. PyKe. 2003. Restoring forbs for sage grouse habitat: fire, microsites, and establishment methods. Restoration Ecology 11:370-377.

Woodward, J., C. Wambolt, J. Newell, and B. Sowell. 2011. Sage-grouse (Centrocercus urophasianus) habitat in central Montana. Natural Resources and Environmental Issues 16(4):1-6.

Wrobleski, D.W., and J.B. Kauffman. 2003. Initial effects of prescribed fire on morphology, abundance and phenology of forbs in big sagebrush communities in southeastern Oregon. Restoration Ecology 11:82-90.

Young, J.A., And F.L. Allen. 1997. Cheatgrass and range science: 1930-1950. Journal of Range Management 50:530-535.

Received 7 January 2016

Accepted 18 May 2016 